\title{
Factors affecting life cycle assessment of milk produced on 6 Mediterranean buffalo farms
}

\author{
G. Pirlo, ${ }^{* 1}$ S. Carè, ${ }^{*}$ V. Fantin,† F. Falconi,ł P. Buttol, † G. M. Terzano,§ P. Masoni,† and C. Pacelli\# \\ ${ }^{*}$ Consiglio per la ricerca e sperimentazione in agricoltura, Centro di ricerca per le produzioni foraggere e lattiero-casearie (CRA-FLC), \\ 26100 Cremona, Italy \\ †ENEA, Italian National Agency for New Technologies, Energy and Sustainable Economic Development, 40129 Bologna, Italy \\ łLCA-lab SRL, 40137 Bologna, Italy \\ $\S$ Consiglio per la ricerca e sperimentazione in agricoltura, Centro di ricerca per il miglioramento genetico e la produzione delle carni, \\ 00016 Monterotondo, Italy \\ \#Dipartimento di Scienze delle Produzioni Animali, Università della Basilicata, 85100 Potenza, Italy
}

\section{ABSTRACT}

This study quantifies the environmental impact of milk production of Italian Mediterranean buffaloes and points out the farm characteristics that mainly affect their environmental performance. Life cycle assessment was applied in a sample of 6 farms. The functional unit was $1 \mathrm{~kg}$ of normalized buffalo milk (LBN), with a reference milk fat and protein content of 8.3 and $4.73 \%$, respectively. The system boundaries included the agricultural phase of the buffalo milk chain from cradle to farm gate. An economic criterion was adopted to allocate the impacts on milk production. Impact categories investigated were global warming (GW), abiotic depletion (AD), photochemical ozone formation (PO), acidification (AC), and eutrophication (EU). The contribution to the total results of the following farm activities were investigated: (1) on-farm energy consumption, (2) manure management, (3) manure application, (4) on-farm feed production (comprising production and application of chemical fertilizers and pesticides), (5) purchased feed production, (6) enteric fermentation, and (7) transport of purchased feeds, chemical fertilizers, and pesticides from producers to farms. Global warming associated with $1 \mathrm{~kg}$ of LBN resulted in $5.07 \mathrm{~kg}$ of $\mathrm{CO}_{2} \mathrm{Eq}$ [coefficient of variation $(\mathrm{CV})=21.9 \%], \mathrm{AD}$ was $3.5 \times 10^{-3} \mathrm{~kg}$ of $\mathrm{Sb} \mathrm{Eq}(\mathrm{CV}$ $=51.7 \%), \mathrm{PO}$ was $6.8 \times 10^{-4} \mathrm{~kg}$ of $\mathrm{C}_{2} \mathrm{H}_{4} \mathrm{Eq}(\mathrm{CV}$ $=28.8 \%), \mathrm{AC}$ was $6.5 \times 10^{-2} \mathrm{~kg}$ of $\mathrm{SO}_{2} \mathrm{Eq}(\mathrm{CV}=$ $30.3 \%)$, and $\mathrm{EU}$ was $3.3 \times 10^{-2} \mathrm{~kg}$ of $\mathrm{PO}_{4}{ }^{3-} \mathrm{Eq}(\mathrm{CV}=$ $36.5 \%)$. The contribution of enteric fermentation and manure application to GW is 37 and $20 \%$, respectively; on-farm consumption, on-farm feed production, and purchased feed production are the main contributors to $\mathrm{AD}$; about $70 \%$ of $\mathrm{PO}$ is due to enteric fermenta-

Received January 31, 2014.

Accepted July 1, 2014.

${ }^{1}$ Corresponding author: giacomo.pirlo@entecra.it tion; manure management and manure application are responsible for 55 and $25 \%$ of $\mathrm{AC}$ and 25 and $55 \%$ of $\mathrm{EU}$, respectively. Methane and $\mathrm{N}_{2} \mathrm{O}$ are responsible for 44 and $43 \%$ of GW, respectively. Crude oil consumption is responsible for about $72 \%$ of $\mathrm{AD}$; contribution of $\mathrm{CH}_{4}$ to $\mathrm{PO}$ is $77 \%$; $\mathrm{NH}_{3}$ is the main contributor to $\mathrm{AC}$ (92\%); $\mathrm{NO}_{3}{ }^{-}$and $\mathrm{NH}_{3}$ are responsible for 55 and $41 \%$ of $\mathrm{EU}$, respectively; contribution of $\mathrm{P}$ to $\mathrm{EU}$ is only $3.2 \%$. The main characteristics explaining the significant variability of life cycle assessment are milk productivity and amount of purchased feed per kilogram of LBN. Improvement of LBN production per buffalo cow is the main strategy for reducing GW and PO; improvement of the efficiency of feed use is the strategy proposed for mitigating $\mathrm{AD}, \mathrm{PO}, \mathrm{AC}$, and $\mathrm{EU}$.

Key words: buffalo milk, life cycle assessment

\section{INTRODUCTION}

The livestock sector is one of the most significant contributors to several important environmental problems, at both the local and global scale, such as climate change, water scarcity, pollution, and loss of biodiversity (Steinfeld et al., 2006). Moreover, livestock farming is responsible for almost two-thirds of ammonia emissions, contributing significantly to acidification of ecosystems (European Environment Agency, 2011); in addition, it requires large amounts of limited natural resources, such as fossil fuels and minerals. For this reason, the Italian Ministry of Agricultural, Food and Forestry Policies (Rome, Italy) has funded a project aimed at investigating the factors affecting environmental performance of the most significant livestock supply chains in Italy. A detailed analysis of the systems has been carried out to quantify the contribution of the single production stages to the total environmental impact and to propose mitigation intervention. Life cycle assessment (LCA) was selected for the analysis, because it allows the environmental assessment of a product or a 
service throughout its life cycle by considering different impact categories. The use of LCA in agricultural and industrial food products has been increasing over the last years due to the growing concern about sustainable food production and consumption.

de Vries and de Boer (2010) compared the results of global warming ( $\mathbf{G W})$, acidification (AC), eutrophication (EU), land use, and energy consumption of some LCA studies on livestock products (pork, chicken, beef, milk, and eggs) up to the farm gate. Other LCA studies of whole production chains of cheese (González-García et al., 2013) and drinking milk (Fantin et al., 2012) confirmed that farm phase is responsible for the greatest part of GW, AC, and EU.

The present study is part of the mentioned project of the Italian Ministry of Agricultural, Food and Forestry Policies and is focused on the application of LCA to the buffalo milk production of 6 farms located in Campania (Italy). The results of the most representative environmental impact categories for the livestock sector are presented (i.e., GW, $\mathrm{AC}$, and $\mathrm{EU}$ ). In addition, abiotic depletion (AD) was included because efficient use of nonrenewable natural resources is crucial for sustainability of livestock activity. Photochemical ozone formation (PO) was also considered, being an indicator of air quality and responsible for significant effects on human health.

The objective of this study was to estimate the environmental impact of buffalo milk production of 6 farms, based on LCA methodology, and to point out the hotspots in the production chain, to suggest the most effective strategies for reducing the environmental impact of buffalo milk production.

\section{MATERIALS AND METHODS}

Life cycle assessment is a standardized methodology (ISO, 2006a,b) for analyzing potential environmental impacts of a product or a service through the entire life cycle. According to the International Organization for Standardization (ISO, 2006a,b), an LCA study consists of 4 main steps: (1) goal and scope definition, (2) life cycle inventory, (3) life cycle impact assessment, and (4) interpretation of results. This study was performed by using SimaPro 7.3 software (PRé Consultants, 2013).

\section{Goal and Scope Definition}

Goal of the Study and Decision Context. The goal of the present study was to evaluate the environmental impact of the production of buffalo milk at the farm gate and to identify the hotspots in the production chain, by applying the standard ISO LCA and the
International Reference Life Cycle Data System Handbook methodology (EC-JRC-IES, 2010) to 6 buffalo farms located in Campania. An attributional approach was applied, according to the archetype A decision context, as defined in the International Reference Life Cycle Data System Handbook (EC-JRC-IES, 2010).

Functional Unit. The functional unit was $1 \mathrm{~kg}$ of normalized buffalo milk (LBN), with a reference milk fat and protein content of 8.3 and $4.73 \%$, respectively. Raw milk was transformed into LBN with the following formula (Di Palo, 1992):

$$
\begin{gathered}
\mathrm{LBN}(\mathrm{kg} / \mathrm{yr})=(\{[(\mathrm{g} \text { of fat } / \mathrm{L}-83) \\
+(\mathrm{g} \text { of } \operatorname{protein} / \mathrm{L}-47.3)] \times 0.00687\}+1) \\
\times \text { milk production }(\mathrm{kg} / \mathrm{yr}) .
\end{gathered}
$$

System Boundaries Definition. The system boundaries considered in the study were from cradle to farm gate (Figure 1). They comprised all the operations for forage production and all those necessary for animal feeding, milking, and care. The system included indirect emissions and consumption derived from the production of chemical fertilizers, seeds, pesticides; production, transport, and processing of purchased feeds; fossil fuel extraction; and maintenance of agricultural equipment and machines. The study did not consider emissions from land use change for the production of on-farm feeds, because no changes in land management practices occurred at the farms investigated. However, background data of purchased feed production, in particular those concerning soybeans in Brazil, included $\mathrm{CO}_{2}$ emissions from land use change. Carbon dioxide emissions from animal respiration and $\mathrm{CO}_{2}$ fixed by plants through photosynthesis were not taken into account because they are not considered a net source under the Kyoto Protocol (IPCC, 2006).

More in detail, direct and indirect consumptions and emissions were attributed to the following activities within the boundaries:

1. on-farm consumption of electricity and fuels for animal feeding, milking, lighting, and cleaning;

2. manure management, including $\mathrm{N}$ and $\mathrm{CH}_{4}$ emissions due to manure storage;

3. manure application, including $\mathrm{N}$ and $\mathrm{P}$ field emissions from manure produced by animals reared at farms;

4. production of on-farm feeds, including the agricultural operations, production, and application of chemical fertilizers and pesticides;

5. production of purchased feeds, including cultivation and processing; 


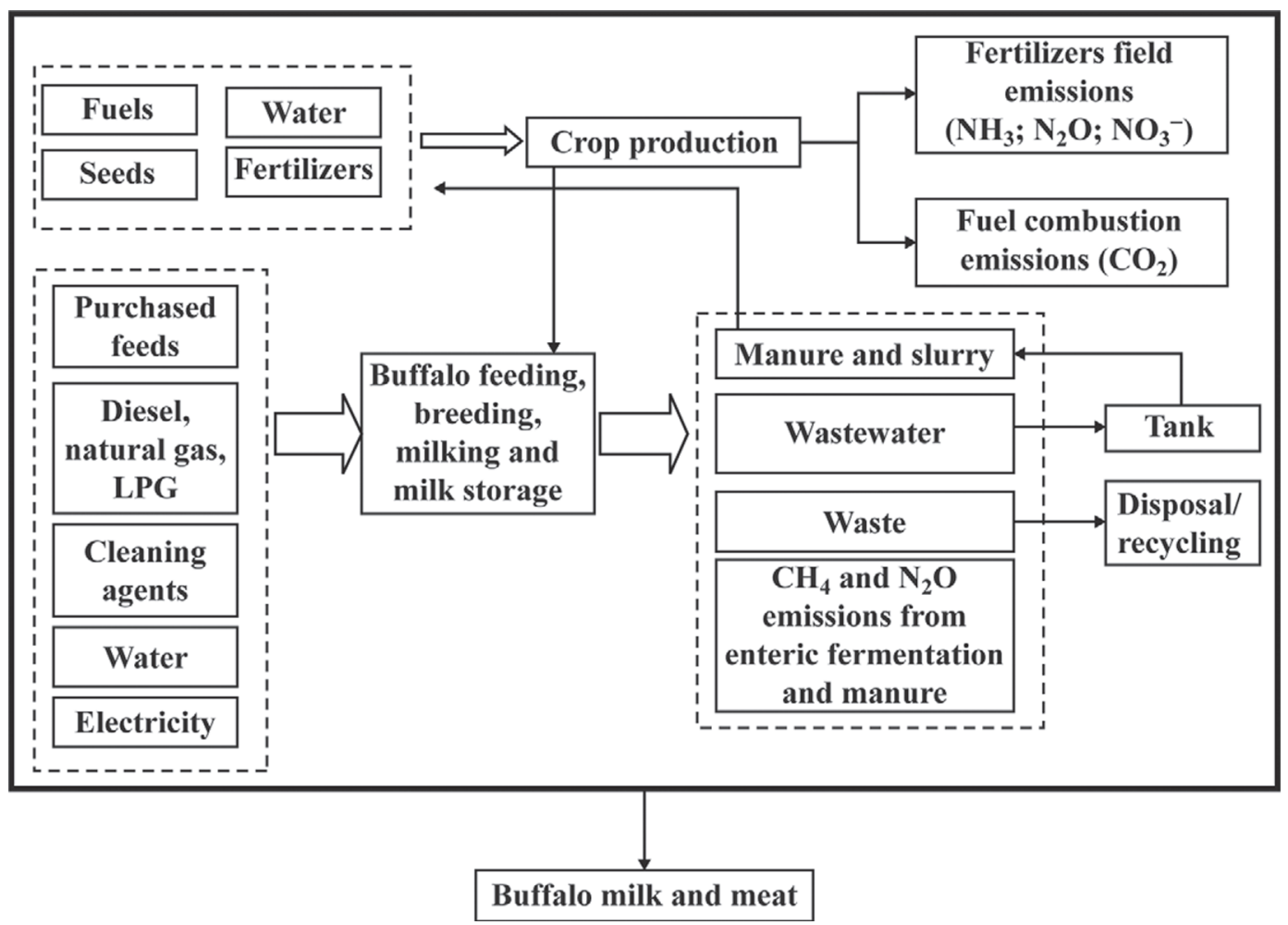

Figure 1. Cradle-to-farm-gate system boundaries of the production of $1 \mathrm{~kg}$ of normalized buffalo milk. The solid line represents the system boundaries of the study. $\mathrm{LPG}=$ liquefied petroleum gas.

6. enteric fermentation, deriving from the fermentative and digestive processes of all animal categories;

7. transport of purchased feeds, chemical fertilizers, and pesticides from producers to the farms;

8. recyclable products (i.e., surplus of manure that can avoid urea production, thanks to its nutrient content).

Allocation Criteria. Buffalo milk production is a typical multifunctional process that coproduces meat from culled buffaloes and surplus calves. Regarding the criteria suggested by ISO (2006a) for partitioning the input and output flows of the production system, subdivision was not viable because milk and meat cannot be produced separately; expansion was not applicable because the goal was to assess the environmental impact of the product milk and substitution would have been controversial because the choice of what product can be replaced by buffalo meat is critical. Therefore, in this study, economic allocation criterion was applied, which was preferred to mass allocation because it better represents societal cause of buffalo farm environmental impacts (Ardente and Cellura, 2012). All coproducts (culled cows and surplus calves) were expressed as kilograms of BW and the contribution of each category was estimated on the basis of its mass and the price per unit of mass paid to the farmer.

Some farms of the sample analyzed produced manure exceeding the requirements of on-farm feed production. This amount was given to some neighboring vegetable producers, who reused it as organic fertilizer. In this study, the surplus of manure was assumed as a substitute for urea and the avoided impacts of this production were calculated.

Data Sources. The 6 farms were selected on the basis of the following criteria: (1) representativeness of buffalo farms operating in Campania, in terms of milk productivity and composition, forage system, and housing system; and (2) adoption of an accounting and management system structured enough to provide detailed and good-quality data for the analysis. Primary data referring to 2010 and concerning crop production and livestock management were collected at each farm by means of a questionnaire including the following items: forage system, fodder production, herd size, herd composition, housing system, yearly milk production, milk composition, diets, manure collection, handling and storage system, and consumption of fertilizers, pesticides, concentrates, electricity, and fuels. Secondary data mainly refer to Italian conditions and calculation methodologies. The Ecoinvent database (v.2.0; Swiss 
Table 1. Main characteristics and inputs of the 6 buffalo farms

\begin{tabular}{|c|c|c|c|c|c|c|c|}
\hline Item & Unit & \multicolumn{6}{|c|}{ Farm } \\
\hline Total cultivated & ha & 45 & 35 & 38 & 20 & 24 & 157 \\
\hline Synthetic N fertilizer & $\mathrm{kg}$ of $\mathrm{N} / \mathrm{ha}$ & 310 & 227 & 349 & 307 & 201 & 4 \\
\hline P fertilizer & $\mathrm{kg}$ of $\mathrm{P}_{2} \mathrm{O}_{5} / \mathrm{ha}$ & 78.8 & 79.0 & 70.8 & 78.2 & 80.3 & 0.0 \\
\hline Buffaloes & No. & 254 & 401 & 465 & 220 & 365 & 460 \\
\hline
\end{tabular}

Centre for Life Cycle Inventories, 2007) and European Reference Life Cycle Database (EC-JRC-IES, 2013) were used for background data. The inventory of milk powder production was based upon Nielsen et al. (2003).

\section{Life Cycle Inventory}

Table 1 shows the main characteristics of the 6 buffalo farms. A wide range of variability existed within the sample in terms of herd size, use of energy, amounts of purchased feeds, and self-sufficiency. Percentage of $\mathrm{CP}$ in the diet of lactating buffaloes ranged between 15.5 and $16.0 \%$ on a DM basis. In all farms, forage system was based on corn silage, with a variable contribution of grass or legumes. Purchased feeds were mostly grains from northern Italy and soybean meal from South America. Grazing system was present only in 1 of the 6 farms analyzed (farm 6), where buffaloes grazed for part of the year. Data concerning milk and meat (expressed as BW) production are shown in Table 2 .

The amount of fuel used in the farms is the sum of the amount bought by the farmers and that used by contractors who often carry out some agricultural operations (i.e., plowing, tilling, and harvesting, among others). The latter was estimated by considering contractors' operations and the corresponding fuel consumption suggested by ENAMA (2005).

Methane emissions arising from enteric fermentation were estimated by using the Intergovernmental Panel Climate Change (IPCC) Tier 2 methodology (Cóndor,
2011), which is based upon the following relationship between gross energy intake and $\mathrm{CH}_{4}$ emissions:

$$
\begin{gathered}
\mathrm{CH}_{4}(\mathrm{~kg} / \text { head per year })=\mathrm{GE} \times(\mathrm{Ym} / 100) \\
\times 365 / 55.65,
\end{gathered}
$$

where GE is the gross energy intake per head per year, $\mathrm{Ym}$ is the $\mathrm{CH}_{4}$ conversion factor, and the factor 55.65 $\left(\mathrm{MJ} / \mathrm{kg}\right.$ of $\mathrm{CH}_{4}$ ) is the energy content of $\mathrm{CH}_{4}$.

The yearly gross energy intake was estimated on the basis of nutrient requirements and the average energy digestibility of feeds (Cóndor et al., 2008), because reliable data on DMI and diet characteristics were not available, due to their large variability during the year. Methane emissions arising during manure storage and following application on land were estimated using the simplified methodology proposed by Cóndor (2011). The emission factor of $0.98 \mathrm{~g}$ of $\mathrm{CH}_{4} / \mathrm{kg}$ of dung DM of the OVERSEER computer model (Wheeler, 2012) was used in the case of grazing, because no specific model for the Italian environment currently exists.

Nitrogen excreted by mature and young buffaloes was estimated through the IPCC (2006) methodology, subtracting the $\mathrm{N}$ retained by the animal from the $\mathrm{N}$ ingested. Nitrous oxide emissions associated with manure storage and management were calculated utilizing the simplified procedure proposed by Cóndor (2011), which distinguishes emissions from solid and liquid manure.

Direct soil $\mathrm{N}_{2} \mathrm{O}$ emissions were computed on the basis of the $\mathrm{N}$ applied in the soil (including organic and

Table 2. Normalized buffalo milk (LBN) and meat (as BW) output

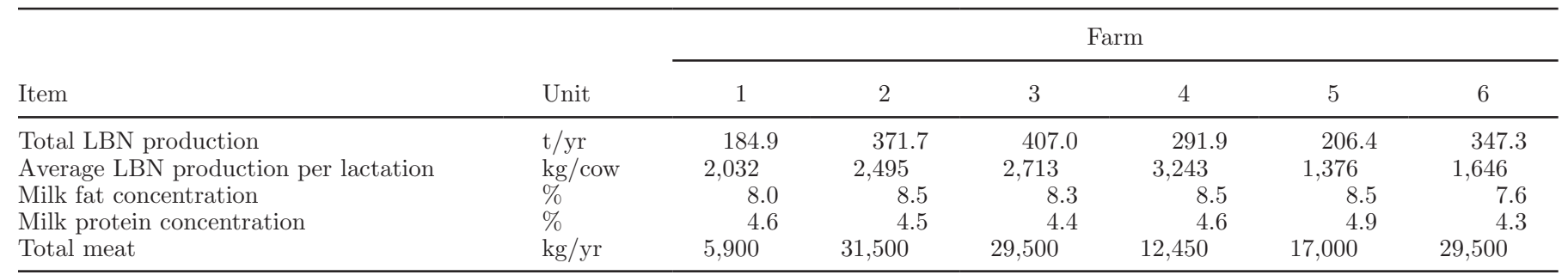


synthetic fertilizers, crop residues, and N-fixing crops), adjusted for the $\mathrm{N}$ lost to volatilization as $\mathrm{NH}_{3}$ and mononitrogen oxides $\left(\mathrm{NO}_{\mathrm{x}}\right)$. The IPCC (2006) methodology was also used for calculating indirect $\mathrm{N}_{2} \mathrm{O}$ emissions, following $\mathrm{N}$ leaching and runoff, and following redeposition of volatilized gases to soils and waters.

Ammonia airborne emissions due to chemical fertilizers use were calculated according to the $\mathrm{NH}_{3}$ emission factors of Cóndor (2011). The yearly $\mathrm{NH}_{3}$ emission factors for manure spreading were assumed to be equal to $5.5 \mathrm{~kg}$ of $\mathrm{NH}_{3}$ per head for calves and heifers and 12.21 $\mathrm{kg}$ of $\mathrm{NH}_{3}$ per head for buffalo cows (Cóndor, 2011).

The yearly $\mathrm{NH}_{3}$ emission factors for animal housing were assumed to be equal to $6.70 \mathrm{~kg}$ of $\mathrm{NH}_{3}$ per head for calves and heifers and $12.67 \mathrm{~kg}$ of $\mathrm{NH}_{3}$ per head for buffalo cows. Yearly $\mathrm{NH}_{3}$ emission factors for manure storage were assumed to be equal to $9.01 \mathrm{~kg}$ of $\mathrm{NH}_{3}$ per head for calves and heifers and $16.69 \mathrm{~kg}$ of $\mathrm{NH}_{3}$ per head for buffalo cows (Cóndor, 2011).

Nitrate waterborne emissions were quantified in agreement with Cóndor $\left(2011 ; 0.3 \mathrm{~kg}\right.$ of $\mathrm{NO}_{3}{ }^{-} \mathrm{N} / \mathrm{kg}$ of $\mathrm{N}$ applied). Phosphorus waterborne emissions were estimated according to the budget farm-gate methodology reported in Dalgaard et al. (2008). Table 3 shows the impact categories and the characterization factors used to evaluate the potential environmental burden of buffalo milk production.

\section{Statistical Analysis}

The REG procedure of SAS (9.1; SAS Institute Inc., Cary, NC) was applied to the linear regression analysis to determine the farms' characteristics that best explain the LCA results. The characteristics were chosen among the indicators of farm size, production performance, and efficiency of resource use. The considered variables were total cultivated area, number of buffaloes, buffaloes per hectare, kilograms of LBN per buffalo cow per year, milk fat percentage, milk protein percentage, kilograms of $\mathrm{N}$ fertilizer per hectare, $1,000 \mathrm{~L}$ of diesel/buffalo, megawatt hours of electricity per buffalo, tonnes of purchased feeds per buffalo, kilograms of $\mathrm{N}$ fertilizer per kilogram of LBN, liters of diesel per kilogram of LBN, megawatt hours of electricity per kilogram of LBN, and purchased feeds per kilogram of LBN. Variables are discussed at coefficient of determination $>0.5$ and $P<0.10$.

\section{RESULTS AND DISCUSSION}

The environmental impacts of the production of $1 \mathrm{~kg}$ of LBN at the 6 buffalo farms are reported in Table 4 . Global warming has the lowest coefficient of variability across farms, whereas AD shows the highest one.

Figure 2 shows the contribution of the farm activities to $\mathrm{GW}, \mathrm{AD}, \mathrm{PO}, \mathrm{AC}$, and $\mathrm{EU}$. In all farms, enteric fermentation is the main contributor to $\mathrm{GW}(37 \%$, on average). Rumen metabolism produces large amounts of $\mathrm{CH}_{4}$, a gas with high global warming potential. Manure application is responsible for $20 \%$ of $\mathrm{GW}$, on average, with little variation across farms. Another important contributor to $\mathrm{GW}$ is purchased feed production, with the exception of farm 1 which is almost self-sufficient. Use of manure surplus contributes less than $5 \%$ to GW. On-farm consumption, on-farm feed production, and purchased feed production are the main contributors

Table 3. Characterization factors of the main elementary flows of the impact categories investigated

\begin{tabular}{|c|c|c|c|c|}
\hline Impact category & Unit & $\begin{array}{l}\text { Main } \\
\text { elementary } \\
\text { flow }^{1}\end{array}$ & $\begin{array}{l}\text { Characterization } \\
\text { factor }\end{array}$ & Source \\
\hline Global warming & $\mathrm{kg}$ of $\mathrm{CO}_{2} \mathrm{Eq}$ & $\begin{array}{l}\mathrm{CO}_{2} \\
\mathrm{CH}_{4} \\
\mathrm{~N}_{2} \mathrm{O}\end{array}$ & $\begin{array}{r}1 \\
25 \\
298\end{array}$ & Forster et al. (2007) \\
\hline Abiotic depletion & $\mathrm{kg}$ of $\mathrm{Sb} \mathrm{Eq}$ & $\begin{array}{l}\text { Hard coal } \\
\text { Soft coal } \\
\text { Natural gas } \\
\text { Crude oil }\end{array}$ & $\begin{array}{l}0.0134 \\
0.00671 \\
0.0187 \\
0.0201\end{array}$ & Guinée et al. (2001) \\
\hline Photochemical ozone formation & $\mathrm{kg}$ of $\mathrm{C}_{2} \mathrm{H}_{4} \mathrm{Eq}$ & $\begin{array}{l}\mathrm{CH}_{4} \\
\mathrm{SO}_{2} \\
\mathrm{CO}\end{array}$ & $\begin{array}{l}0.006 \\
0.048 \\
0.027\end{array}$ & $\begin{array}{l}\text { Jenkin and Hayman (1999) } \\
\text { Derwent et al. (1998) }\end{array}$ \\
\hline Acidification & $\mathrm{kg}$ of $\mathrm{SO}_{2} \mathrm{Eq}$ & $\begin{array}{l}\mathrm{NH}_{3} \\
\mathrm{NO}_{\mathrm{x}} \\
\mathrm{SO}_{2}\end{array}$ & $\begin{array}{l}1.6 \\
0.5 \\
1.2\end{array}$ & Huijbregts (1999) \\
\hline
\end{tabular}

\footnotetext{
${ }^{1} \mathrm{NO}_{\mathrm{x}}=$ mononitrogen oxides.
} 
Table 4. Environmental impacts of the production of $1 \mathrm{~kg}$ of normalized buffalo milk (LBN) at the 6 buffalo farms

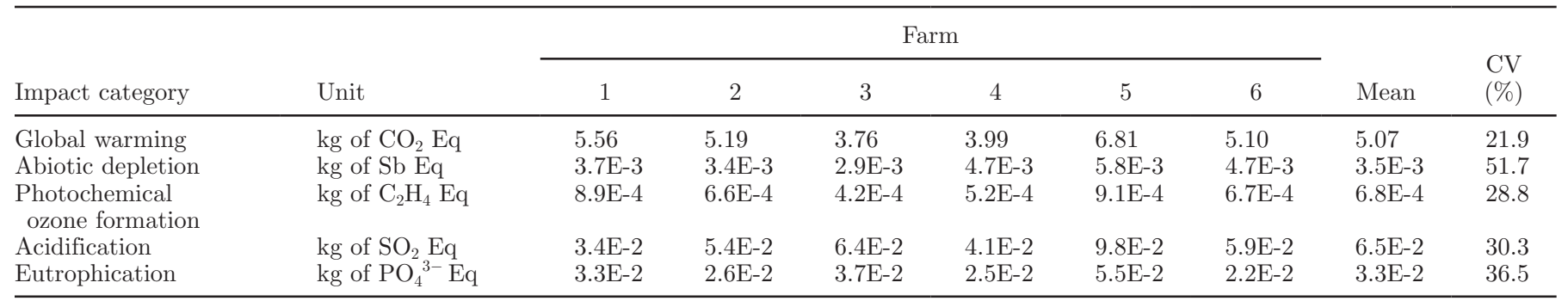

to $\mathrm{AD}$; these activities consume electricity for lighting and milking, and fossil fuels for agricultural operations. The surplus of manure in farm 3 , farm 5 , and farm 6 contributes to lower the $\mathrm{AD}$ impact $(6 \%$, on average), because it is used in neighboring farms as a substitute for urea. Despite some differences among farms, approximately $70 \%$ of $\mathrm{PO}$ is due to enteric fermentation. Manure management is the main contributor to $\mathrm{AC}$ (more than 50\%), followed by manure application. The latter is the main contributor to $\mathrm{EU}$ (35\%, on average).

\section{Comparison with Other Studies}

To our knowledge, no other LCA studies about buffalo milk production have been published, whereas several LCA studies on cow milk can be found in the literature. Although buffaloes and cattle differ for productivity and milk characteristics (i.e., the 2 systems cannot be considered interchangeable), their production systems are similar. In particular, both are reared in confined systems, requiring considerable amounts of
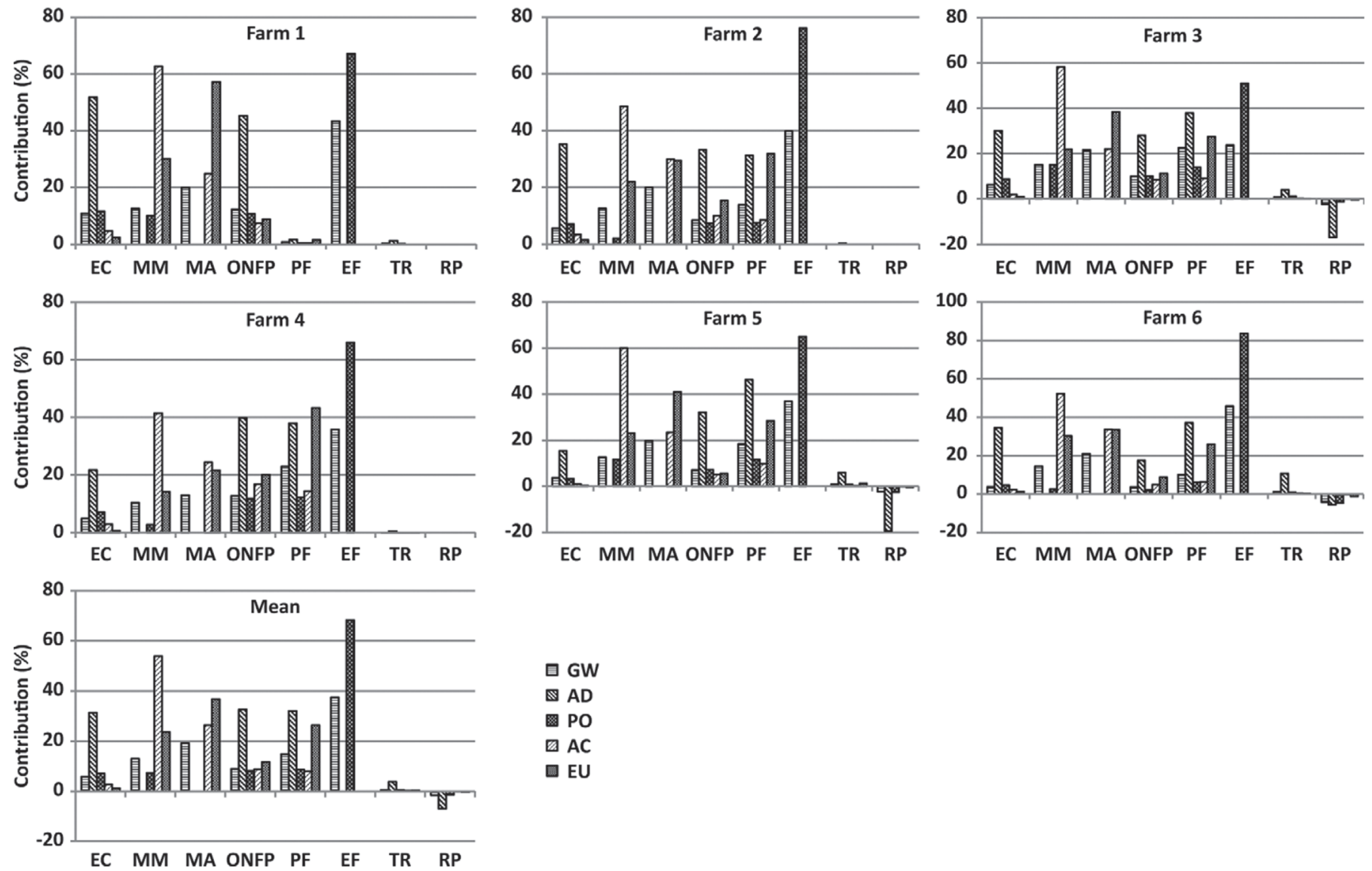

Figure 2. Contribution of on-farm consumption (EC), manure management (MM), manure application (MA), on-farm feed production $(\mathrm{ONFP})$, purchased feed production $(\mathrm{PF})$, enteric fermentation $(\mathrm{EF})$, transport (TR), and recyclable products (RP) to global warming (GW), abiotic depletion (AD), photochemical ozone formation (PO), acidification (AC), and eutrophication (EU). 
concentrates, fertilizers, pesticides, and fossil fuels. For these reasons, the results of cow milk LCA studies have been used here as a yardstick for comparison. de Vries and de Boer (2010) reviewed several LCA studies about milk production published from 2001 to 2009. The GW effect associated with $1 \mathrm{~kg}$ of milk is approximately 1 $\mathrm{kg}$ of $\mathrm{CO}_{2} \mathrm{Eq}$, with little variability; the effects on $\mathrm{AC}$ and EU are much more variable, ranging from 0.001 to $0.011 \mathrm{~kg}$ of $\mathrm{SO}_{2} \mathrm{Eq}$ and from 0.004 to $0.012 \mathrm{~kg} \mathrm{PO}_{4}{ }^{3-}$ Eq, respectively. These results are much lower than the ones obtained in our study. However, 2 main differences should be highlighted: the higher nutrient content of 1 $\mathrm{kg}$ of LBN compared with $1 \mathrm{~kg}$ of dairy cow milk (more than 2 times for fat and about 1.5 times for protein) and the lower milk productivity, even if corrected for milk nutrient contents. Regarding $\mathrm{AD}$ and $\mathrm{PO}$, Castanheira et al. (2010) found that $1.4 \times 10^{-3} \mathrm{~kg}$ of Sb Eq and $1.9 \times 10^{-4} \mathrm{~kg}$ of $\mathrm{C}_{2} \mathrm{H}_{4} \mathrm{Eq}$ are associated with $1 \mathrm{~kg}$ of cattle milk.

\section{Farm Characteristics and Environmental Impact}

We observed a negative relationship between LBN productivity ( $\mathrm{kg} /$ buffalo cow) and GW; in contrast, a positive relationship exists between GW and use of purchased feeds per unit of product ( $\mathrm{kg}$ of purchased feed $/ \mathrm{kg}$ of LBN; Table 5). In dairy cattle, the negative relationship between milk production and carbon footprint (de Boer et al., 2011) is well known, because the increase in production reduces the incidence of maintenance on total nutrient requirements. We observed a positive relationship between $\mathrm{GW}$ and consumption of purchased feeds, because their production requires considerable amounts of fossil fuels for fertilizer, seeds, pesticides, and agricultural operations; furthermore, cultivation is also responsible for $\mathrm{N}_{2} \mathrm{O}$ emissions from the soil. On the basis of this result, increasing on-farm feed production and improving on-farm feed quality seem to be effective for mitigating greenhouse gas emissions. Casey and Holden (2005), who used the same approach, found that the average milk production per cow can explain the variability of greenhouse gas emissions associated with $1 \mathrm{~kg}$ of cattle ECM and pointed out no correlations with other variables.

The results show a positive relationship between the average amount of purchased feeds per buffalo and AD. This is explained by the considerable amount of natural resources, especially fossil fuels, necessary for cropping and transporting purchased feeds. Almost $60 \%$ of the variability of $\mathrm{AD}$ is explained by purchased feed per kilogram of LBN.

We observed a negative relationship between PO and average milk production. As already pointed out, $\mathrm{CH}_{4}$ from enteric fermentation is by far the main factor

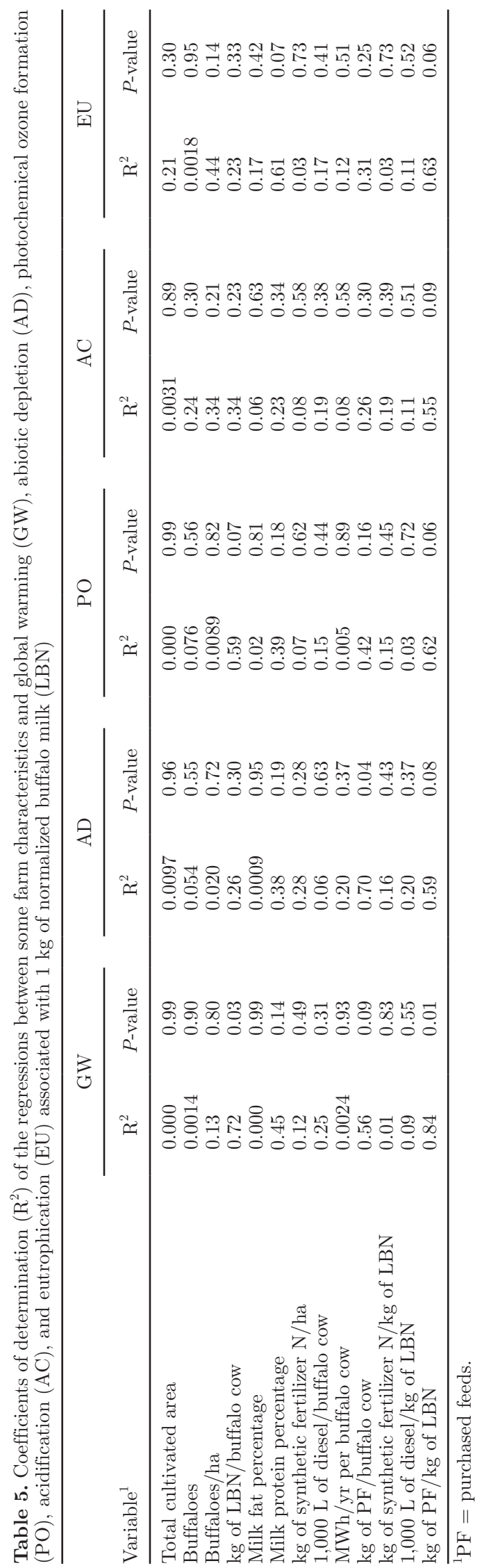

Journal of Dairy Science Vol. 97 No. 10, 2014 
responsible for PO (Figure 2), notwithstanding its low photochemical ozone formation potential, and increasing the average milk production could be an effective mitigation strategy. A positive relationship between $\mathrm{PO}$ and purchased feed per kilogram of LBN was observed.

A positive relationship exists between $\mathrm{AC}$ and purchased feeds per kilogram of LBN. The use of purchased feeds determines a flow of nutrients (especially $\mathrm{N})$ responsible for the decrease in $\mathrm{pH}$ in water and soil. Optimization of the use of feeding resources should be the first choice for mitigating AC.

The amount of purchased feeds per kilogram of LBN has a positive relationship with EU. Similarly to PO, the efficient use of nutrients is fundamental to reduce the nutrient enrichment of water bodies.

\section{Main Sources of Environmental Impacts and Mitigation Strategies}

Table 6 shows the main emissions affecting GW, $\mathrm{AD}, \mathrm{PO}, \mathrm{AC}$, and EU. Methane and $\mathrm{N}_{2} \mathrm{O}$ are the main contributors to GW. Enteric fermentation accounts for $87 \%$ of total $\mathrm{CH}_{4}$, whereas fermentations of manure OM in the barn and during storage are responsible for the remaining $\mathrm{CH}_{4}$ emissions. Over the last few years, several effective measures for reducing enteric $\mathrm{CH}_{4}$ emissions from dairy cattle have been identified (Knapp et al., 2014), which could be partially introduced into the buffalo production system as well. For example, the genetic selection for more productive buffaloes seems to be very promising in reducing enteric $\mathrm{CH}_{4}$ emissions per functional unit and, consequently, GW impact. Improvements in nutrition and feeding, such as lipid administration, could also be considered. On the other hand, some further strategies, such as the increase of concentrates in the diet, or the increase in the use of maize silage have already been adopted extensively in the farms we examined.

The remaining part of $\mathrm{CH}_{4}(13 \%)$ is emitted during manure storage in the barn, in dung heaps, or in tanks. Production of $\mathrm{CH}_{4}$ proceeds more rapidly in a crowded environment under anaerobic conditions, and is favored when manure is managed with a liquid-based system. However, because this system has already been adopted in all farms in the sample examined, some benefits could be obtained with the addition of straw (Yamulki, 2006), which reduces the anaerobic conditions.

Nitrous oxide is another important contributor to GW of buffalo milk production. Nitrogen excreted by animals and $\mathrm{N}$ contained in synthetic fertilizers are the main source of $\mathrm{N}_{2} \mathrm{O}$ deriving from the processes of nitrification and denitrification. A portion of the excreted
$\mathrm{N}$ is emitted in the atmosphere as $\mathrm{N}_{2} \mathrm{O}$ when manure is in the barn or during storage. In LCA studies of milk production, the contribution of $\mathrm{N}_{2} \mathrm{O}$ from manure management to the total greenhouse emissions ranges from 7 to $10 \%$ (de Boer et al., 2011). In the present LCA study, the contribution of $\mathrm{N}_{2} \mathrm{O}$ to $\mathrm{GW}$ is about $16 \%$. Both amounts of $\mathrm{N}$ excreted and manure management system are key factors affecting $\mathrm{N}_{2} \mathrm{O}$ emissions from manure. Nitrogen losses can be reduced by improving diet $\mathrm{N}$ efficiency (i.e., by producing the same amount of milk with a lower amount of feed protein). The manure management system adopted in the farms investigated in this study is unfavorable for $\mathrm{N}_{2} \mathrm{O}$ production, because liquid manure systems create an anaerobic environment that limits $\mathrm{N}_{2} \mathrm{O}$ production. It is worth noting that the use of straw for bedding has conflicting effects on $\mathrm{GW}$, because it reduces $\mathrm{CH}_{4}$ emissions but increases $\mathrm{N}_{2} \mathrm{O}$ emission. Another relevant source of greenhouse gas is the $\mathrm{N}_{2} \mathrm{O}$ emitted from the soil after spreading of manure and application of synthetic fertilizers. In the present analysis, the contribution of manure application, synthetic fertilizer application, and production of purchased feeds to total $\mathrm{N}_{2} \mathrm{O}$ emissions is 43,10 , and $30 \%$, respectively. Because of this complexity, a wide variety of measures can be taken to reduce $\mathrm{N}_{2} \mathrm{O}$ emissions from the soil. Several reviews focused attention to mitigation measures for reducing $\mathrm{N}_{2} \mathrm{O}$ after either organic or inorganic fertilizer application. One of the most updated is that by de Boer et al. (2011). A part of these measures refers to strategies concerning different

Table 6. Emissions and sources responsible of global warming $(\mathrm{GW})$, abiotic depletion (AD), photochemical ozone formation (PO), acidification (AC), and eutrophication (EU)

\begin{tabular}{|c|c|c|c|}
\hline $\begin{array}{l}\text { Impact } \\
\text { category }\end{array}$ & Contributor $^{1}$ & $\begin{array}{c}\text { Mean } \\
(\%)\end{array}$ & $\begin{array}{l}\text { CV } \\
(\%)\end{array}$ \\
\hline \multirow[t]{3}{*}{ GW } & $\mathrm{CH}_{4}$ & 43.5 & 17.3 \\
\hline & $\mathrm{N}_{2} \mathrm{O}$ & 43.3 & 17.1 \\
\hline & $\mathrm{CO}_{2}$ & 13.2 & 65.8 \\
\hline \multirow[t]{4}{*}{$\mathrm{AD}$} & Oil & 72.3 & 16.4 \\
\hline & Natural gas & 15.6 & 6.4 \\
\hline & Hard coal & 9.3 & 50.0 \\
\hline & Other sources & 2.3 & 50 \\
\hline \multirow[t]{4}{*}{$\mathrm{PO}$} & $\mathrm{CH}_{4}$ & 76.9 & 9.2 \\
\hline & $\mathrm{SO}_{2}$ & 11.4 & 35.8 \\
\hline & $\mathrm{CO}$ & 7.7 & 25.3 \\
\hline & Other sources & 4.0 & 28.5 \\
\hline \multirow[t]{3}{*}{$\mathrm{AC}$} & $\mathrm{NH}_{3}$ & 92.2 & 2.5 \\
\hline & $\mathrm{NO}_{\mathrm{x}}$ & 5.1 & 18.0 \\
\hline & $\mathrm{SO}_{2}$ & 2.6 & 0.5 \\
\hline \multirow[t]{4}{*}{ EU } & $\mathrm{NO}_{3}^{-}$ & 54.7 & 16.5 \\
\hline & $\mathrm{NH}_{3}$ & 41.1 & 22.7 \\
\hline & $\mathrm{P}$ & 3.2 & 90.0 \\
\hline & $\mathrm{NO}_{\mathrm{x}}$ & 1.0 & 90.0 \\
\hline
\end{tabular}

${ }^{1} \mathrm{NO}_{\mathrm{x}}=$ mononitrogen oxides. 
application systems such as season of application or precise fertilizer distribution.

In another review, Schils et al. (2013) reported some other considerations about synthetic $\mathrm{N}$ fertilizer performance and slurry injection techniques. Fertilizers containing $\mathrm{NO}_{3}{ }^{-}$increase $\mathrm{N}_{2} \mathrm{O}$ emissions compared with urea or $\mathrm{NH}_{4}{ }^{+}$-based fertilizers. Mitigation measures based on fertilizer selection and application can be profitably adopted in intensive producing systems, such as that examined in the current study. In this case, environmental and economic benefits are interconnected, because these strategies lead to a reduction of purchased fertilizers.

In this study, the contribution of $\mathrm{CO}_{2}$ to $\mathrm{GW}$ is $13 \%$. Carbon dioxide emissions are related to milking, lighting, refrigerating, and feeding (farm consumption); agricultural operations and synthesis of $\mathrm{N}$ fertilizers for production of on-farm and purchased feeds; and the transport of inputs from the producers or suppliers to the farm. In LCA studies on dairy cows, higher $\mathrm{CO}_{2}$ emissions are associated with intensive production systems rather than extensive systems. Pastoral systems are characterized by smaller contributions of $\mathrm{CO}_{2}$ emissions to GW compared with confined systems, because fewer agricultural operations are carried out and cattle are fed with lower amounts of concentrates (O'Brien et al., 2012). A high coefficient of determination between the use of purchased feeds per unit of product and GW was observed in the present study, which means that its reduction can influence greenhouse gas emissions. As we observed wide variability across farms, the efficiency of use of purchased feeds can be improved.

In all the farms investigated, the most significant contributions to $\mathrm{AD}$ come from crude oil (72\%), natural gas, and coal. Crude oil is mainly related to diesel consumption for on-farm and purchased feed agricultural operations, so that significant improvement could be obtained in this impact category by decreasing the use of diesel at the farm and increasing the efficiency in the use of purchased and on-farm feeds.

Methane is the major contributor to PO. O'Brien et al. (2012) estimated that enteric $\mathrm{CH}_{4}$ represents about $88 \%$ of the total $\mathrm{CH}_{4}$ emissions in a dairy herd. We found that enteric $\mathrm{CH}_{4}$ was $87 \%$ of total emissions, on average. Consequently, the strategies that should be adopted for mitigating $\mathrm{PO}$ are the same ones already described for reducing the contribution of enteric $\mathrm{CH}_{4}$ to GW.

Ammonia is largely the main output affecting the AC impact category. In the farms investigated, the main sources of $\mathrm{NH}_{3}$ are manure in the barn and during storage and manure after application, with 63 and $24 \%$ of total $\mathrm{NH}_{3}$ emissions, respectively. Emissions of
$\mathrm{NH}_{3}$ from chemical fertilizer application for on-farm and purchased feeds are much lower $\left(14 \%\right.$ of total $\mathrm{NH}_{3}$ emissions).

Similarly to $\mathrm{N}_{2} \mathrm{O}, 2$ factors determine $\mathrm{NH}_{3}$ emissions from manure and soil: the amount of $\mathrm{N}$ excreted and the systems of manure management and utilization. An effective strategy for reducing $\mathrm{N}$ excretion and $\mathrm{NH}_{3}$ emissions is to increase milk production per buffalo cow, similarly to what was observed in dairy herds (Powell et al., 2013). Diet $\mathrm{N}$ utilization can be improved also through feeding strategies, able to reduce $\mathrm{N}$ intake while maintaining similar levels of productivity (de Boer et al., 2011). However, reduction of purchased feed results to be the most effective strategy to reduce the nutrient load in the farm, because extensive use of purchased feeds and wide variability of consumption were found in the farms investigated.

The main contributors to $\mathrm{EU}$ are $\mathrm{NO}_{3}{ }^{-}, \mathrm{NH}_{3}$, and, to a lesser extent, $\mathrm{P}$ emissions. Consequently, efforts for reducing EU should focus on $\mathrm{NO}_{3}{ }^{-}$and $\mathrm{NH}_{3}$ emissions. Mitigation measures concerning $\mathrm{NH}_{3}$ have already been discussed above. Regarding $\mathrm{NO}_{3}{ }^{-}$, the model used for estimating $\mathrm{N}$ leaching and runoff is based on a fixed coefficient of $0.3 \mathrm{~kg}$ of $\mathrm{N}^{-N_{3}}{ }^{-} / \mathrm{kg}$ of $\mathrm{N}$ applied to the soil, whereas $\mathrm{N}$ leaching is also affected by soil characteristics and agricultural practices. Strategies for reducing $\mathrm{NO}_{3}{ }^{-}$leaching are mainly based on timing manure or fertilizer application with vegetable growth. Similar to $\mathrm{GW}$ and $\mathrm{AC}$, the main strategy to reduce emissions of $\mathrm{NO}_{3}{ }^{-}$and $\mathrm{NH}_{3}$ is to improve the efficiency in the use of on-farm and purchased feeds.

\section{CONCLUSIONS}

This LCA study considered 5 environmental impact categories associated with the production of $1 \mathrm{~kg}$ of LBN in 6 buffalo farms. The study also showed that wide variability exists in the environmental performances of the farms, especially for $\mathrm{AD}$. This means that the environmental performance of some farms can be improved. Moreover, the study showed that farm activities give different contributions to the impact categories. Enteric fermentation, manure application, and purchased feed production are the main sources of greenhouse gas emissions. In particular, enteric $\mathrm{CH}_{4}$ and $\mathrm{N}_{2} \mathrm{O}$ are responsible for about $90 \%$ of the emissions associated with GW. On-farm consumption, on-farm feed production, and purchased feed production are responsible for $\mathrm{AD}$ to the same extent. Crude oil is the main nonrenewable natural resource consumed in the 6 buffalo farms. Enteric fermentation is the activity determining the greatest part of $\mathrm{PO}$, because of the $\mathrm{CH}_{4}$ emissions deriving from the fermentative and 
digestive processes in the rumen. Manure management is the most important farm activity affecting AC. Ammonia represents more than $90 \%$ of the substances causing acidification of soil and water. The activity that most contributes to EU is manure application and $\mathrm{NO}_{3}{ }^{-}$and $\mathrm{NH}_{3}$ emissions are the main causes of this impact category. The characteristics that best explain the variability of LCA results among farms are milk productivity and the amount of purchased feed per kilogram of LBN. The improvement of LBN production per buffalo cow allows reducing $\mathrm{GW}$ and $\mathrm{PO}$. The improvement of the efficiency in using purchased feeds has a positive effect on $\mathrm{AD}, \mathrm{PO}, \mathrm{AC}$, and $\mathrm{EU}$. The results show a wide margin for improvement; increasing milk productivity and optimizing use of feeds are the main strategies that farms should adopt to mitigate the environmental impact of buffalo milk production.

\section{ACKNOWLEDGMENTS}

This study has been carried out in the framework of the project "Development of animal models for sustainability," funded by the Italian Ministry of Agricultural, Food and Forestry Policies (MiPAAF, Rome, Italy).

\section{REFERENCES}

Ardente, F., and M. Cellura. 2012. Economic allocation in life cycle assessment. J. Ind. Ecol. 16:387-398.

Casey, J. W., and N. M. Holden. 2005. The relationship between greenhouse gas emissions and the intensity of milk production in Ireland. J, Environ. Qual. 34:429-436.

Castanheira, E. G., A. C. Dias, L. Arroja, and R. Amaro. 2010. The environmental performance of milk production on a typical Portuguese dairy farm. Agric. Syst. 103:498-507.

Cóndor, R. D. 2011. Agricoltura: Emissioni nazionali in atmosfera dal 1990 al 2009. Rapporto ISPRA 140/2011. Istituto Superiore per la Protezione e la Ricerca Ambientale (ISPRA), Rome, Italy.

Cóndor, R. D., L. Valli, G. De Rosa, A. Di Francia, and R. De Lauretis. 2008. Estimation of the methane emission factor for the Italian Mediterranean buffalo. Animal 2:1247-1253.

Dalgaard, R., J. Schmidt, N. Halberg, P. Christensen, M. Thrane, and W. A. Pengue. 2008. LCA of soybean meal. Int. J. Life Cycle Assess. 13:240-254.

de Boer, I. J. M., C. Cederberg, S. Eady, S. Gollnow, T. Kristensen, M. Macleod, M. Meul, T. Nemecek, L. T. Phong, G. Thoma, H. M. G. van der Werf, A. G. Williams, and M. A. Zonderland-Thomassen. 2011. Greenhouse gas mitigation in animal production: Towards an integrated life cycle sustainability assessment. Curr. Opin. Environ. Sustain. 3:423-431.

de Vries, M., and I. J. M. de Boer. 2010. Comparing environmental impacts for livestock products: A review of life cycle assessments. Livest. Sci. 128:1-11.

Derwent, R. G., M. E. Jenkin, S. M. Saunders, and M. J. Pilling. 1998. Photochemical ozone creation potentials for organic compounds in Northwest Europe calculated with a master chemical mechanism. Atmos. Environ. 32:2429-2441.

Di Palo, R. 1992. Produzione di latte nella bufala con diete tradizional e con l'impiego di acidi grassi. PhD Thesis. University of Naples, Naples, Italy.
EC-JRC-IES (European Commission Joint Research Centre-Institute for Environment and Sustainability). 2010. International Reference Life Cycle Data System (ILCD) Handbook-General guide for Life Cycle Assessment-Detailed guidance. EUR 24708 EN. Publications Office of the European Union, Luxembourg.

EC-JRC-IES (European Commission Joint Research Centre-Institute for Environment and Sustainability). 2013. European reference Life Cycle Database (ELCD). Accessed Aug. 2, 2013. http://lca. jrc.ec.europa.eu/lcainfohub/datasetArea.vm.

ENAMA (Ente Nazionale per la Meccanizzazione Agricola). 2005. Prontuario dei consumi di carburante per l'impiego agevolato in agricoltura. Roma 2005. Accessed Nov. 15, 2012. http://www.enama.it/ $\mathrm{php} /$ pageflip.php?pdf=enema_int_prontuario.pdf\&dir=/it/pdf/ monografie.

European Environment Agency. 2011. European Union emission inventory report 1990-2009 under the UNECE Convention on longrange transboundary air pollution (LRTAP). EEA Technical Report No. 9/2011. European Environment Agency, Copenhagen, Denmark.

Fantin, V., P. Buttol, R. Pergreffi, and P. Masoni. 2012. Life cycle assessment of Italian high quality milk production. A comparison with an EPD study. J. Clean. Prod. 28:150-159.

Forster, P., V. Ramaswamy, P. Artaxo, T. Berntsen, R. Betts, D. W. Fahey, J. Haywood, J. Lean, D. C. Lowe, G. Myhre, J. Nganga, R. Prinn, G. Raga, M. Schulz, and R. Van Dorland. 2007. Changes in atmospheric constituents and in radiative forcing. Chapter 2 in Climate Change 2007: The Physical Science Basis. Contribution of Working Group I to the Fourth Assessment Report of the Intergovernmental Panel on Climate Change. S. Solomon, D. Qin, M. Manning, Z. Chen, M. Marquis, K. B. Averyt, M. Tignor, and H. L. Miller, ed. Cambridge University Press, Cambridge, UK, and New York, NY.

González-García, S., É. G. Castanheira, A. C. Dias, and L. Arroja. 2013. Environmental performance of a Portuguese mature cheesemaking dairy mill. J. Clean. Prod. 41:65-73.

Guinée, J. B., M. Gorrée, R. Heijungs, G. Huppes, H. Kleijn, A. de Koning, L. van Oers, A. Wegener Sleeswijk, S. Suh, H. A. Udo de Haes, H. de Bruijn, R. van Duin, M. A. J. Huijbregts, E. Lindeijer, A. A. H. Roorda, B. L. van der Ven, and B. P. Weidema. 2001. Life cycle assessment: An operational guide to the ISO standards. Ministry of Housing, Spatial Planning and the Environment (VROM), The Hague, the Netherlands, and Centre of Environmental Science, Leiden University (CML), Leiden, the Netherlands.

Heijungs, R., J. B. Guinée, G. Huppes, R. M. Lankreijer, H. A. Udo de Haes, A. Wegener Sleeswijk, A. M. M. Ansems, P. G. Eggels, R. van Duin, and H. P. de Goede. 1992. Environmental life cycle assessment of products: Guide and backgrounds. Centre of Environmental Science (CML), Leiden University, Leiden, the Netherlands.

Huijbregts, M. 1999. Life-cycle impact assessment of acidifying and eutrophying air pollutants. Calculation of equivalency factors with RAINS-LCA. Interfaculty Department of Environmental Science, Faculty of Environmental Science, University of Amsterdam, Amsterdam, the Netherlands.

IPCC (Intergovernmental Panel on Climate Change). 2006. 2006 IPCC Guidelines for National Greenhouse Gas Inventories: Volume 4: Agriculture, Forestry and other Land Use. http://www.ipcc-nggip. iges.or.jp/public/2006gl/vol4.html.

ISO (International Organization for Standardization). 2006a. Environmental management-Life cycle assessment-Principles and framework. ISO 14040. ISO, Geneva, Switzerland.

ISO (International Organization for Standardization. 2006b. Environmental management-Life cycle assessment-Requirements and guidelines. ISO 14044. ISO, Geneva, Switzerland.

Jenkin, M. E., and G. D. Hayman. 1999. Photochemical ozone creation potentials for oxygenated volatile organic compounds: Sensitivity to variations in kinetic and mechanistic parameters. Atmos. Environ. 33:1275-1293.

Knapp, J. R., G. L. Laur, P. A. Vadas, W. P. Weiss, and J. M. Tricarico. 2014. Invited review: Enteric methane in dairy cattle pro- 
duction: Quantifying the opportunities and impact of reducing emissions. J. Dairy Sci. 97:3231-3261.

Nielsen, P. H., A. M. Nielsen, B. P. Weidema, R. Dalgaard, and N. Halberg. 2003. LCA Food Database. Accessed March 2014. http:// www.lcafood.dk.

O'Brien, D., L. Shalloo, J. Patton, F. Buckley, C. Grainger, and M. Wallace. 2012. A life cycle assessment of seasonal grass-based and confinement dairy farms. Agric. Syst. 107:33-46.

Powell, J. M., M. MacLeod, T. V. Vellinga, C. Opio, A. Falcucci, G. Tempio, H. Steinfeld, and P. Gerber. 2013. Feed-milk-manure nitrogen relationships in global dairy production systems. Livest. Sci. 152:261-272.

PRé Consultants. 2013. SimaPro 7.3.3 software. Accessed March 2014 http://www.pre-sustainability.com/.
Schils, R. L. M., J. Eriksen, S. Ledgard, T. V. Vellinga, P. J. Kuikman, J. Luo, S. O. Petersen, and G. L. Velthof. 2013. Strategies to mitigate nitrous oxide emissions from herbivore production systems. Animal 7(Suppl. s1):29-40.

Steinfeld, H., P. Gerber, T. Wassenaar, V. Castel, M. Rosales, and C. de Haan. 2006. Livestock's long shadow. Food Agriculture Organization of the United Nations (FAO), Rome, Italy.

Swiss Centre for Life Cycle Inventories. 2007. The Ecoinvent database v.2.0. Accessed March 2014. http://www.ecoinvent.org/database/.

Wheeler, D. M. 2012. OVERSEER ${ }^{\circledR}$ Technical manual. AgResearch Ltd. Accessed June 2013. http://www.overseer.org.nz.

Yamulki, S. 2006. Effect of straw addition on nitrous oxide and methane emissions from stored farmyard manures. Agric. Ecosyst. Environ. 112:140-145. 